\title{
Biotechnology Research
}

http:/www.journals.zu.edu.eg/journalDisplay.aspx?Journalld=1\&queryType=Master

\section{ANTICANCER EFFECTS OF TOW TRADITIONAL DRINKS HIBISCUS (Hibiscus sabdariffa LINN) AND LIQUORICE (Glycyrrhiza glabra)}

\author{
Ahmed N. Elkattan ${ }^{1 *}$, S.S. El-Saadany ${ }^{1}$, A.L. ElSayed ${ }^{1}$, A.M. Gomaa ${ }^{1}$ and J. Abdalmuneim ${ }^{2}$ \\ 1. Biochem. Dept., Fac. Agric., Zagazig Univ., Egypt \\ 2. Fac. Vet., Zagazig Univ., Egypt
}

Received: 03/12/2018 ; Accepted: 05/02/2019

\begin{abstract}
Breast cancer (MCF-7), as well as liver cancer (HepG2), were the leader among new cancer cases. The objective of this study is to assess the viability percentage of tow traditional drinks (hibiscus and liquorice extracts) toward human breast and liver cancer cell lines at different concentrates from 250 to $5000 \mu \mathrm{g} / \mathrm{ml}$ in hibiscus extract and from 50 to $3000 \mu \mathrm{g} / \mathrm{ml}$ in liquorice extract. The viability percentage of hibiscus on breast and liver cancer cell lines were $86.9 \%$ and $84.7 \%$ at $5000 \mu \mathrm{g} / \mathrm{ml}$, respectively. The $\mathrm{IC}_{50}$ of the hibiscus extract were $18478.6 \mu \mathrm{g} / \mathrm{ml}$ and 16159 $\mu \mathrm{g} / \mathrm{ml}$ breast and liver cancer. In addition, the viability percentage of liquorice extract on breast and liver cancer cell lines were determined. Results revealed that liquorice extract has possessed high anticarcinogenic properties it was zero (\%) at $3000 \mu \mathrm{g} / \mathrm{ml}$ for breast cancer and $5 \%$ for liver cancer at same concentration, the $\mathrm{IC}_{50}$ was $491.7 \mu \mathrm{g} / \mathrm{ml}$ in breast cancer and was $125 \mu \mathrm{g} / \mathrm{ml}$ in liver cancer cell line. DNA damage was determined to detect oxidative DNA damage in HepG2 cell line. This enhances the role of these traditional drinks especially liquorice as anti-cancer agents.
\end{abstract}

Key words: Breast cancer (MCF-7), liver cancer (HepG2), traditional drinks, Hibiscus sabdariffa linn, liquorice (Glycyrrhiza glabra).

\section{INTRODUCTION}

Hibiscus sabdariffa linn known as Roselle is a yearly bush ordinarily used to make jams and refreshments. The dried blossom of $H$. sabdariffa remove has indicated elevated amounts of polyphenol, flavonoid, and anthocyanin which was seen to be related to anticancer impacts as indicated by Naveen et al. (2012).

Licorice, the dry base of Glycyrrhiza glabra, has been utilized for therapeutic purposes for centuries; stores of licorice were found in the tombs of Egyptian pharaohs, including that of King Tut. Its history is painstakingly evaluated by Davis and Morris (1991).

Cancer growth advancement is a multi-step process where different oncogenic transformations offer ascent to disease cells with various hereditary imperfections, which can vary even inside individual tumors. This decent variety is a huge

\footnotetext{
* Corresponding author: Tel. : +201000654724

E-mail address: ahmd89822@gmail.com
}

impediment in disease treatment, so cell lines built up from human tumors tests can be a useful device for screening pertinent medications. For visualization of malignant growth affectability to specific therapeutics, coordinate cytotoxicity measures in disease cells can be joined with information in regards to the outflow of qualities fundamental for antitumor activity as per (Schilsky, 2010). The huge qualities of individual bosom malignancies are the declaration of estrogen, progesterone, and human epidermal development factor receptor 2 (HER2/CD340), and the proposed kind of treatment is situated to a limited extent on these attributes were surveyed by Rivenbark et al. (2013). Among them, the estrogen receptor (ER) status is more basic for foreseeing the reaction to hormonal treatment, while progesterone receptor (PGR) status has stayed disputable by Singhal et al. (2016). 
Essential liver malignant growth (counting hepatocellular carcinoma and intrahepatic cholangiocarcinoma) is the second reason for the disease-related demise and one of the tumors with as yet expanding incidence rate (Kassebaum et al., 2014). Hepatocellular carcinoma, a noteworthy essential liver malignant growth obsessive sort, demonstrates low multiyear survival rate $(<15 \%)$ attributable to its late finding and traded off hidden liver capacity (Sapisochin et al., 2016). Albeit careful resection or transplantation enhances the survival rate of patients, there is still no successful treatment for cutting-edge patients who are ineligible for a medical procedure, bringing about just a middle in general survival of 6.6 months for these patients (Cheng et al., 2016). Accordingly, it is basic to investigate powerful and safe prognostic biomarkers for early finding and helpful focuses to enhance treatment procedures.

In the present study, we expect to investigate the practicality level of tow conventional beverages (hibiscus and liquorice extracts) toward human breast and liver cancer cell lines at various concentrates, to improve the job of these customary beverages as hostile to malignancy specialists.

\section{MATERIALS AND METHODS}

\section{Materials}

Egyptian hibiscus Hibiscus sabdariffa Linn and liquorice Glycyrrhiza glabra were purchased from local market.

\section{Reagents}

Primary cells or established cell lines, Neutral red (3-amino-7-dimethylamino-2- methyl-phenazine hydrochloride) (Sigma, cat. No. N4638) (see REAGENT SETUP), Dulbecco's formulation PBS tablets (Bio-Whittaker, cat. no. 17-512F) (see REAGENT SETUP), Trypsin-EDTA $(0.05 \%$ $W / V$ trypsin, $0.02 \% W / V$ EDTA) (BioWhittaker, cat. no. BE17-161E), Medium adequate for cell requirements (e.g., Eagle's minimum essential medium (EMEM)) (BioWhittaker, cat. No. BE12-125F), Medium additives adequate for cell requirements (e.g., 10\% fetal or newborn calf serum, heat inactivated) (GIBCO, cat. No.
10108-165); 200 mM L-Gin (BioWhittaker, cat. No. BE17-605E); $50 \mathrm{mg} 11$ gentamycin sulfate (BioWhittaker, cat. No. 17- 518Z); 2 mg 1_1 Fungizone (BioWhittaker, cat. No. BE17636E); nonessential amino acids (BioWhittaker, cat. no. BE13-114E). m CRITICAL Complete medium with additives and serum should be stored at $41^{\circ} \mathrm{C}$ for no longer than 2 weeks, Glacial acetic acid (Sigma, cat. No. 537020), Ethanol 96\% (Riedel-de Hae"n, cat. No. $32294), 0.4 \%(W / V)$ Trypan blue in $0.9 \% \mathrm{Nacl}$ solution (Sigma, cat. No. T8154) and Glutaraldehyde $5 \%$ by dilution of the commercial $25 \%$ (Sigma, cat. No. G6257) (optional)

\section{Samples Preparation}

The plant materials hibiscus and liquorice were dried in an oven at $50 \pm 1^{\circ} \mathrm{C}$ then powdered using a lab grinder and stored in air- tight jars maintained at $4^{\circ} \mathrm{C}$ till use. Dried materials $(10 \mathrm{~g})$ were extracted with distilled water by soaking at room temperature for $48 \mathrm{hr}$. The extract was centrifuged at $2000 \mathrm{rpm} 15 \mathrm{~min}$. (Jouan, MR 1822, France). Extraction and filtration were repeated until the residue was colorless. The solvent was removed under vacuum at $40^{\circ} \mathrm{C}$ using a rotary evaporator (Laborota 4000efficient, Heildolph, Germany). Extracts were freeze-dried using lyophilizer. The obtained powder were kept in light- protected containers at $-18^{\circ} \mathrm{C}$ until further use.

\section{Neutral Red Uptake Assay for the Estimation of Cell Viability/Cytotoxicity}

The neutral red uptake assay provides a quantitative estimation of the number of viable cells in a culture. It is one of the most used cytotoxicity tests with many biomedical and environmental applications according to Guillermo et al. (2008).

\section{Analysis of DNA Damage by Comet Assay}

The comet assay was carried out by the method previously described by Collins and his collaborators (Collins, 2004) with some modification (Yedjou and Tchounwou, 2007). Cells were counted (10,000 cells/well) and aliquots of $100 \mu \mathrm{l}$ of the cell suspension were placed in each well of 96 plates, treated with $100 \mu 1$ aliquot of either media or different concentrates from 250 to $5000 \mu \mathrm{g} / \mathrm{ml}$ in 


\section{Zagazig J. Agric. Res., Vol. 46 No. (1) 2019}

hibiscus extract and from 50 to $3000 \mu \mathrm{g} / \mathrm{ml}$ in liquorice extract, respectively and incubated in a $5 \% \mathrm{CO}_{2}$ at $37^{\circ} \mathrm{C}$ for $2 \mathrm{hr}$. After incubation, the cells were centrifuged, washed with PBS free calcium and magnesium, and re-suspended in $100 \mu \mathrm{l}$ PBS. In a $2 \mathrm{ml}$ tube, $50 \mu \mathrm{l}$ of the cells suspension and $500 \mu \mathrm{l}$ of melted Agarose were mixed and $75 \mu 1$ was pipetted onto a pre-warmed comet slide. The side of the pipette tip was used to spread completely agarose/cells over the sample area. The slides were placed flat in the dark at $4{ }^{\circ} \mathrm{C}$ for 10 minutes to allow the mixture to solidify and then immersed in a prechilled lysis solution at $4^{\circ} \mathrm{C}$ for 40 minutes. The slides were removed from lysis solution, tapped, and immersed in alkaline solution for 40 minutes at room temperature in the dark. The slides were washed twice for $5 \mathrm{~min}$ with Tris-Borate-EDTA (TBE). The slides were electrophoresed at low voltage $\left(300 \mathrm{~mA}, 25 \mathrm{~V}, 4^{\circ} \mathrm{C}\right)$ for 20 minutes. The slides were placed in $70 \%$ ethanol for $5 \mathrm{~min}$, removed, tapped, and air-dried for overnight. The slides were stained with SYBR Green stain designed for the Comet Assay and allowed to air dry at room temperature for six hours. SYBR Green-stained comet slides were viewed with an Olympus fluorescence microscope and analyzed using LAI's Comet Assay Analysis System software (Loates Associates, Inc. Westminster, MD).

\section{RESULTS AND DISCUSSION}

\section{Inhibition of Cell Viability}

The viability percentage of hibiscus on breast and liver cancer cell lines were $86.9 \%$ and $84.7 \%$ at $5000 \mu \mathrm{g} / \mathrm{ml}$, respectively. The $\mathrm{IC}_{50}$ of the hibiscus and liquorice extract were $18478.6 \mu \mathrm{g} / \mathrm{ml}$ and $16159 \mu \mathrm{g} / \mathrm{ml}$, against breast and liver cancer respectively. In addition, the viability percentage of liquorice extract on breast and liver cancer cell lines were determined and the results revealed that liquorice extract has possessed high anticarcinogenic properties, it was zero (\%) at 3000 $\mu \mathrm{g} / \mathrm{ml}$ for breast cancer and 5\% for liver cancer at the same concentration, $\mathrm{The}^{\mathrm{IC}} \mathrm{I}_{50}$ of liquanice was $491.7 \mu \mathrm{g} / \mathrm{ml}$ aginst breast cancer and was $125 \mu \mathrm{g} / \mathrm{ml}$ aginst liver cancer cell line (Table 1 and Fig. 1). Licorice flavonoids have become one of the hotspots of pharmacological studies for their structural diversity and important pharmacological activities of the isolated flavonoids, including chalcones, isoflavones, isoflavans, flavonones, flavanonols, $\mathbf{1 1 7}$ isoflavenes, and arylcoumarins as reported by Fu et al. (2013). Liquiritin, isoliquiritin and liquiritigenin are considered to be the main flavonoids of licorice, exhibited a variety of biological properties including antitumor, antidepressant, neuroprotective, antioxidant and anti-inflammatory stated by Zhou and Ho (2014). Licochalcone A, an oxygenated chalcone in licorice, was reported to possess antitumor, antimalarial, anti-metastatic, chemopreventive, antibacterial, and anti-spasmodic activity presented by Kim et al. (2010). Glycycoumarin, a representative coumarin in $G$. uralensis, showed antithrombotic and antispasmodic activities (Qiao et al., 2014). Some isoflavans derived flavonoids in licorice, such as glabridin, licoricidin and licorisoflavan A showed antiinflammatory, antioxidative and antitumor activities (Fu et al., 2013).

According to Duh and Yen (1997), the Roselle extract is an electron donor and can scaven free radicals to convert them into more stable products and terminate radical chain reactions. Besides demonstrating the potent antioxidant activity of the extract, they revealed that the extract does not only induce mutagenicity but possibly play an important role as dietary antioxidants after ingestion, in the chemical protection against oxidative damage of cell membranes. Thus, the extract may be a strong chemopreventive agent in carcinogenesis. Antioxidant activity of the Roselle extracts correlated strongly to its anthocyanin content (Tsai et al., 2002). Anthocyanins (extracted from the dried calyx of $H$. sabdariffa) are natural polyphenolic compounds in the red pigments of Roselle and several other intensely- colored plants. The Hibiscus anthocyanins were found to possess antioxidant bioactivity both in vivo and in vitro (Wang et al., 2000), in addition to this the anthocyanins in Roselle calyx are found to not only possess antioxidant activity (Tsuda $\boldsymbol{e t} \boldsymbol{a l}$., 2000), but also mediate other physiological functions related to cancer suppression (Meiers et al., 2001). Hibiscus anthocyanins (HAs) extracted from the Roselle calyx was found to have a concentration-dependent inhibitory effect on the growth of several cell lines, including MCF-7 cells (Chang et al., 2005). 
Table 1. Percentage cell viability and $\mathrm{IC}_{50}$ of Hibiscus and Liquorice of MCF-7 and HepG2 cell lines

\begin{tabular}{|c|c|c|}
\hline \multirow[t]{3}{*}{ Concentration $(\mu \mathrm{g} \backslash \mathrm{ml})$} & \multicolumn{2}{|c|}{ Viability (\%) } \\
\hline & Breast cancer (MCF-7) & Liver cancer (HepG2) \\
\hline & \multicolumn{2}{|c|}{ Hibiscus } \\
\hline$\overline{5000}$ & 86.9 & 84.7 \\
\hline 3000 & 95 & 87.4 \\
\hline 2000 & 97 & 92.4 \\
\hline 1000 & 98 & 95.8 \\
\hline 500 & 100 & 97 \\
\hline 250 & 100 & 98.3 \\
\hline \multirow[t]{2}{*}{$\mathrm{IC}_{50}$} & $18478.6 \mu \mathrm{g} \backslash \mathrm{ml}$ & $16159 \mu \mathrm{g} \backslash \mathrm{ml}$ \\
\hline & \multicolumn{2}{|c|}{ Liquarice } \\
\hline 3000 & 0 & 5 \\
\hline 2000 & 0 & 4.5 \\
\hline 1000 & 0 & 8.8 \\
\hline 500 & 51.6 & 12 \\
\hline 250 & 65 & 29.8 \\
\hline 50 & 100 & 73 \\
\hline $\mathrm{IC}_{\mathbf{5 0}}$ & $491.7 \mu \mathrm{g} \backslash \mathrm{ml}$ & $125 \mu \mathrm{g} \backslash \mathrm{ml}$ \\
\hline
\end{tabular}

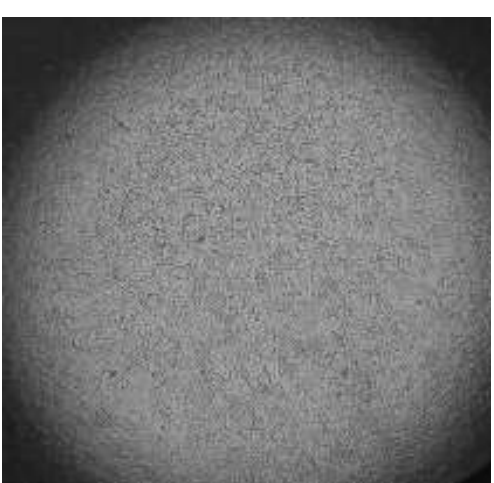

Negative control MCF-7

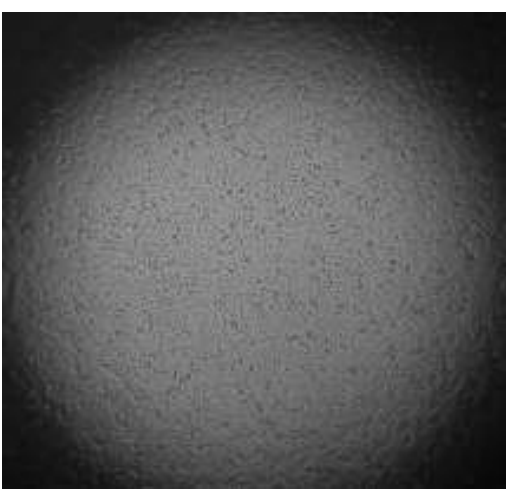

Negative HepG2

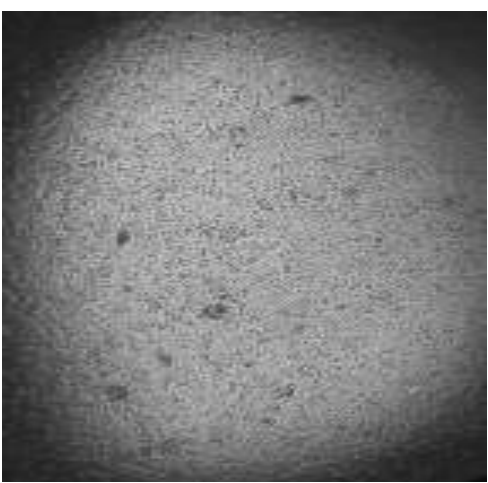

Hibiscus $3000 \mu \mathrm{g} / \mathrm{ml}$

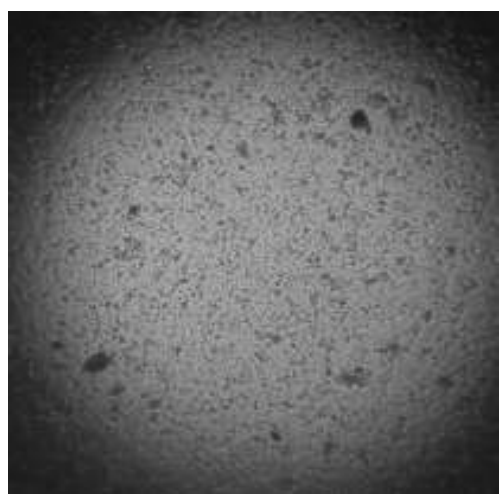

Hibiscus $3000 \mu \mathrm{g} / \mathrm{ml}$

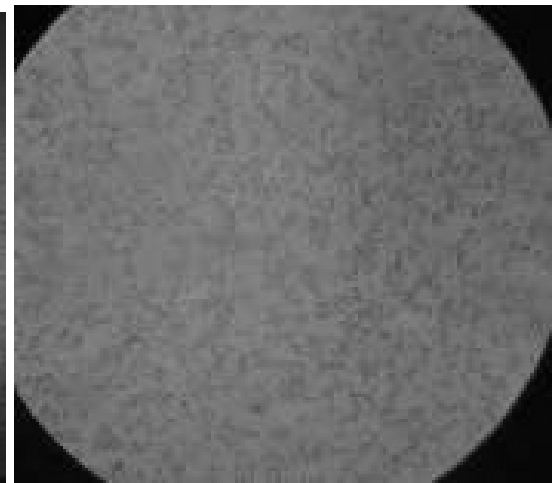

Liquorice $3000 \mu \mathrm{g} / \mathrm{ml}$

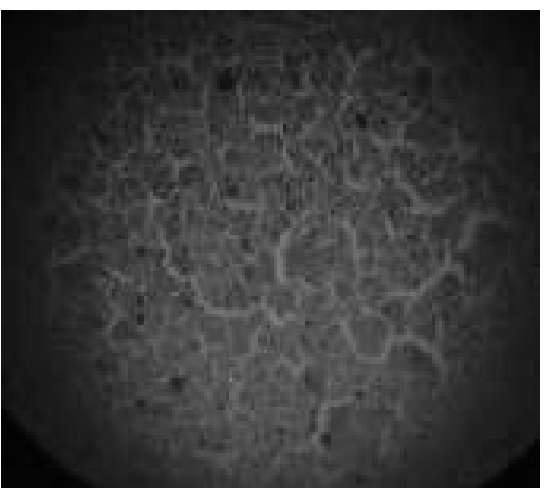

Liquorice $3000 \mu \mathrm{g} / \mathrm{ml}$

Fig. 1. Morphologically cytotoxic effects of negative, hibiscus and liquorice extracts on MCF-7 and HepG2 cells 


\section{Induction of DNA Damage}

The adverse impacts of high liquorice Glycyrrhiza glabra extract $(3000 \mu \mathrm{g} / \mathrm{ml})$ on liver malignant growth (HepG2), there stays extensive uncertainty about the cell and molecular mechanisms of activity of liquorice remove in HepG2 cells.

Table 2 and Figs. 2 and 3 demonstrated the related DNA harm in HepG2 cells; by the methods for soluble single cell gel electrophoresis (Comet) measure. It could be noticed that liquorice extract has a solid genotoxic potential and is capable of causing DNA harm in malignant growth cells. The study outcomes showed that liquorice extract actuates genotoxic impacts to HepG2 cells in a portion subordinate form, it was $24 \%$ suggestive clear proof that liquorice concentrate might be an intense DNA harming operator against bosom and liver malignant growth when utilized at high dosages $(3000 \mu \mathrm{g} / \mathrm{ml})$, these outcomes were compared by negative control (17\%).

Cell passing is thought to happen at any rate by two different ways that incorporate apoptosis and necrosis. Apoptosis is a functioning and physiological method of cell passing that is accepted to be intervened by dynamic characteristic instruments, albeit extraneous $\mathbf{1 1 9}$ elements can contribute according to Padanilam (2003). For the most part, it demonstrates no incendiary morphological changes of cell shrinkage which incorporate cytoplasmic and atomic buildup, chromatin buildup (pyknosis), requested DNA fracture (karyorrhexis), blebbing of the plasma layer, development of apoptotic bodies (cell discontinuity of film bound sections) and presentation of surface particles, for example, phosphatidylserine (PS) on the plasma film to encourage finish phagocytosis of apoptotic cells these were reported by Wyllie (1994). Conversely, rot is an uncontrolled cell passing that is portrayed by the dynamic loss of cytoplasmic film respectability, the quick convergence of $\mathrm{Na}^{+}, \mathrm{Ca}^{2+}$, and water, bringing about cytoplasmic swelling and atomic pyknosis Barros stated by Barros et al. (2001). The last component prompts cell fracture and arrival of lysosomal and granular substance into the encompassing extracellular space, with ensuing aggravation (Majno and Joris, 1995).

Table 2. DNA damage of control and liquorice extract on HepG2 cells

\begin{tabular}{lccccc}
\hline Sample & $\begin{array}{c}\text { Comet } \\
\mathbf{( \% )}\end{array}$ & $\begin{array}{c}\text { Tail Length } \\
\mathbf{( p x )}\end{array}$ & $\begin{array}{c}\text { DNA in Tail } \\
\mathbf{( \% )}\end{array}$ & $\begin{array}{c}\text { Tail } \\
\text { Moment }\end{array}$ & $\begin{array}{c}\text { Olive tail } \\
\text { moment }\end{array}$ \\
\hline Control & 17 & 4.909091 & 3.69653 & 0.247281 & 0.837201 \\
liquorice extract & 27 & 11.33333 & 3.784216 & 0.454482 & 0.949797 \\
\hline
\end{tabular}
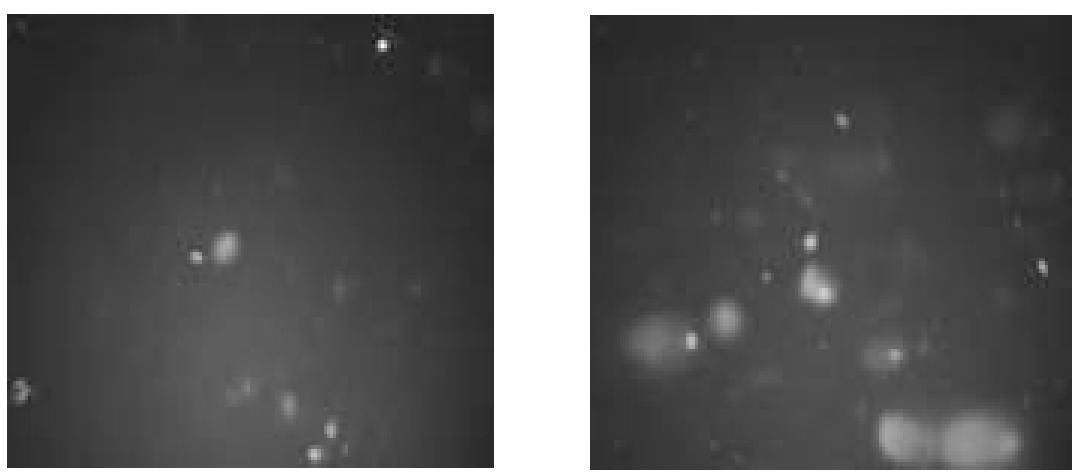

(a)

Fig. 2. DNA damage of control on HepG2 cells (a) 

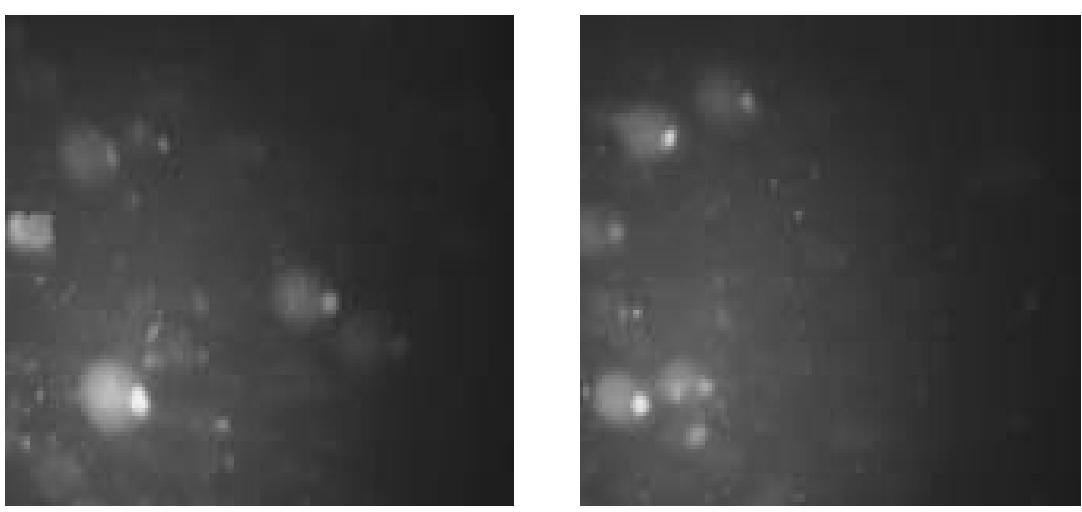

(b)

Fig. 3. DNA damage of liquorice extract on HepG2 cells (b)

\section{REFERENCES}

Barros, L.F., T. Hermosilla and J. Castro (2001). Necrotic volume increase and the early physiology of necrosis. Comp Biochem Physiol A MolIntegr Physiol 130: 401-409.

Chang, Y.C., H.P. Huang, J.D. Hsu, S.F. Yang and C.J. Wang (2005). Hibiscus anthocyanins rich extract-induced apoptotic cell death in human promyelocytic leukemia cells. Toxicol. Appl. Pharm., 205: 201-212.

Cheng, A.L., S. Thongprasert, H.Y. Lim, W. Sukeepaisarnjaroen, T.S. Yang, C.C. Wu, Y. Chao, S.L. Chan, M. Kudo and M. Ikeda (2016). Randomized, open-label phase 2 study comparing frontline dovitinib versus sorafenib in patients with advanced hepatocellular carcinoma. Hepatol., 64: 774-784.

Collins, A.R. (2004). The comet assay for DNA damage and repair: principles, applications, and limitations. Mol. Biotechnol., 26: 249-261.

Duh, P.D. and G.C. Yen (1997). Antioxidative activity of three herbal water extracts. J. Food Chem., 60: 639-645.

Davis, E.A. and D.J. Morris (1991). Medicinal uses of licorice through the millennia: The good and plenty of it Mol. Cell. Endocrinol., $78: 1$.

Fu, Y., J. Chen, Y.J. Li, Y.F. Zheng and P. Li (2013). Antioxidant and anti-inflammatory activities of six flavonoids separated from licorice. Food Chem., 141: 1063-1071.

Guillermo, R., A.D. Peso and J.L. Zurita (2008).
Neutral red uptake assay for the estimation of cell viability/cytotoxicity. Natur. Prot., 3 (7): 1125- 1131 .

Kim, J.K., E.K. Shin, J.H. Park, Y.H. Kim and J.H. Park (2010). Antitumor and antimetastatic effects of licochalcone A in mouse models. $\mathrm{J}$ Mol. Med., 88: 829-838.

Kassebaum, N.J., A. Bertozzi-Villa, M.S. Coggeshall, K.A. Shackelford, C. Steiner, K.R. Heuton, D. Gonzalez-Medina, R. Barber, C. Huynh and D. Dicker (2014). Global, regional, and national levels and causes of maternal mortality during 1990-2013: A systematic analysis for the Global Burden of Disease Study 2013. Lancet 384: 980-1004.

Majno, G. and I. Joris (1995). Apoptosis, oncosis, and necrosis. An overview of cell death. Ame. J. Pathol., 146: 3-15.

Meiers, S., M. Kemeny, U. Weyang, R. Gastpar, E. von Angerer and D. Marko (2001). The anthocyanins cyanidin and delphinidin are potent inhibitors of the epidermal growthfactor receptor. J. Agric. Food Chem., 49: $958-962$.

Naveen, K.D., S. Shikha, V. Cijo-George, P.K. Suresh and K.R. Ashok (2012). Anticancer and anti-metastatic activities of Rheum emodi rhizome chloroform extracts. Asian J. Pharm. Clin. Res., 5: 189-194.

Padanilam, B.J. (2003) Cell death induced by acute renal injury: a perspective on the contributions of apoptosis and necrosis. Ame. J. Physiol. Renal. Physiol., 284: 608- 627. 
Qiao, X., C.F. Liu, S. Ji, X.H. Lin and D.A. Guo (2014). Simultaneous determination of five minor coumarins and flavonoids in Glycyrrhiza uralensis by solid-phase extraction and highperformance liquid chromatography/ electrospray ionization tandem mass spectrometry. Planta. Med., 80: 237-242.

Rivenbark, A.G., S.M. O'Connor and W.B. Coleman (2013). Molecular and cellular heterogeneity in breast cancer: challenges for personalized medicine. Ame. J. Pathol., 183: 1113-24.

Schilsky, R.L. (2010). Personalized medicine in oncology: the future is now. Nat Rev Drug Discov., 9 : 363-366.

Singhal, H., M.E. Greene, G. Tarulli, A.L. Zarnke, R.J. Bourgo and M. Laine (2016). Genomic agonism and phenotypic antagonism between estrogen and progesterone receptors in breast cancer. Sci Adv., 2(6): e1501924

Sapisochin, G., N. Goldaracena, J.M. Laurence, M. Dib, A. Barbas, A. Ghanekar, S.P. Cleary, L. Lilly, M.S. Cattral and M. Marquez (2016). The extended Toronto criteria for liver transplantation in patients with hepatocellular carcinoma: A prospective validation study. Hepatol., 64 : 2077-2088.
Tsai, P.J., J. McIntosh, P. Pearce, B. Camden and B.R. Jordan (2002). Anthocyanin and antioxidant capacity in Roselle (Hibiscus sabdariffa L.) extract. Food Res. Int., 35: 351-356.

Tsuda, T., F. Horio and T. Osawa (2000). The role of anthocyanins as an antioxidant under oxidative stress in rats. Biofactors, 13: 133139.

Wang, C.J., J.M. Wang, W.L. Lin, C.Y. Chu, F.P. Chou and T.H. Tseng (2000). Protective effect of Hibiscus anthocyanins against tertbutyl hydroperoxide-induced hepatic toxicity in rats. Food Chem. Toxicol., 38: 411-416.

Wyllie, A.H. (1994). Death from inside out: an overview. Philos Trans R. Soc. Lond B. Biol. Sci., 345: 237-241.

Yedjou, C.G. and P.B. Tchounwou (2007). In vitro cytotoxic and genotoxic effects of arsenic trioxide on human leukemia (HL-60) cells using the MTT and alkaline single cell gel electrophoresis (Comet) assays. Mol. Cell. Biochem., 301: 123-130

Zhou, Y. and W.S. Ho (2014). Combination of liquiritin, isoliquiritin and isoliquirigenin induce apoptotic cell death through upregulating p53 and p21 in the A549 nonsmall cell lung cancer cells. Oncol Rep., 31: 298-304. 
تأثثر تناول المشروبات التقليدية مثل العرقسوس والكركديه على مقاومتها للخلايا السرطانية

$$
\begin{aligned}
& \text { احمد نبيل القطان' - السيد سليمان السعدنى' - عبدالعليم إسماعيل السيد' }
\end{aligned}
$$

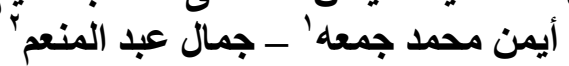

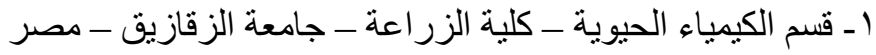

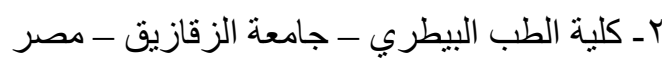

سرطان الكبد وسرطان الثدي من أكثر الأورام السرطانية شيو عا و أكثر ها شر اسة، يهدف البحث لتقدير إمكانية استخدام

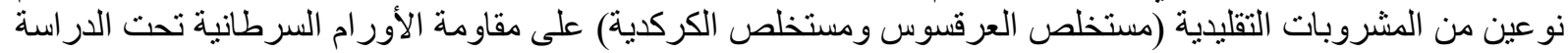

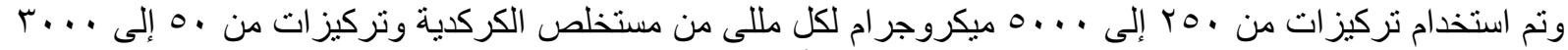

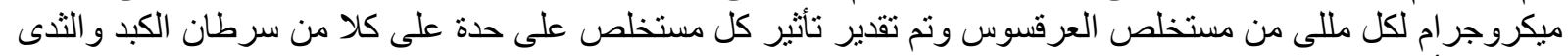

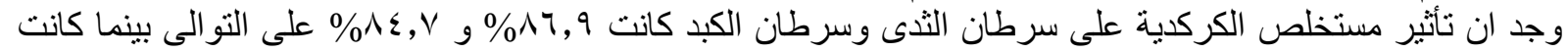

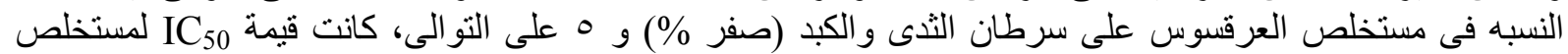

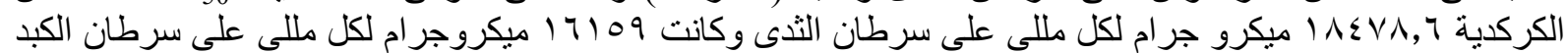

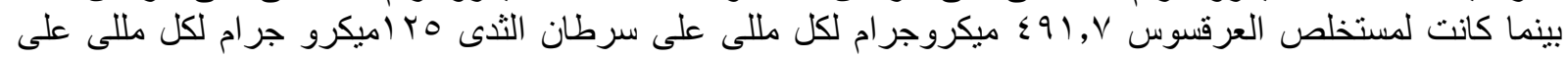

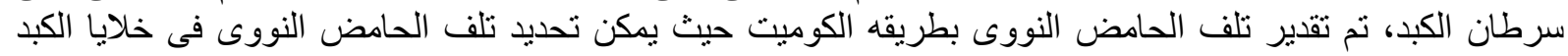

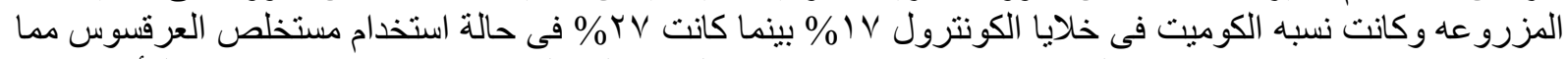

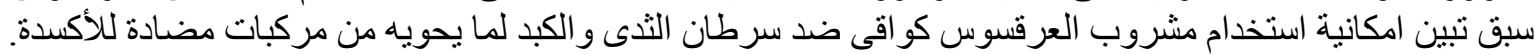

أستاذ الكيمياء الحيوية ـ كلية الزر اعة - جامعة القاهرة.

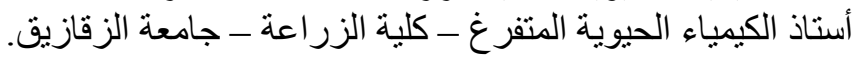

